Received: Jul 25, 2017; Accepted: Aug 15, 2017; Published: Aug 28, 2017; Paper Id: IJLSROCT20171

\title{
INTRODUCTION
}

Library network centres like INFLIBNET, DELNET and other intuitional repository centres are significant initiatives of Ministry of Human Resource Development (MHRD) which promote technology and research in the country. Those initiatives have helped university libraries to be in a better position to provide stateof-the-art resources through traditional and modern systems. Many university libraries have developed their library websites or are in the process of development. The tremendous growth and continuous development of ICT, the role of library and information centers becomes more responsive in making the user oriented techno-savvy. The technological advancement is dominated not only the formats of web enabled information resources and services of the modern libraries, but also creating the user friendly environment to maximize usage of the information resources and services available in the university libraries. In an effort to reach to the end users for accessing the library via their ICT devices, many libraries have been adopted library consortia to extending their resources and services including virtual reference. The advanced technology now allows users to submit their queries to the library at anytime from anywhere in the world.

The developments in ICT and their subsequent inclusion in library and information centres have been forced information professionals to change the way they are functioning at present and the popularity and an overwhelming attention is being given to the web-based information resources and services in libraries and 
information centres. The university libraries wish to attract prospective students, research scholars, and faculty members must show significant improvements in the library infrastructure and libraries are procuring more and more electronic resources like e-journals, e-books, online databases, e-theses and dissertations and other electronic materials. The efforts of libraries in providing users with an integrated way of checking the availability of an e-resource and services in all possible formats have necessitated and properly designed web based services to end users (Cox and Yeates, 2003).

\section{REVIEW OF RELATED STUDIES}

The present study takes a broad view of web $\square$ based library services, focusing on different web $\square$ based library services as well as the whole spectrum of library services of university libraries. Efforts were made to use available original articles/abstracts for the review. Besides, other information resources available on the internet have been used as the sources of information for the purpose of the study. Many numbers of studies have been conducted on the web enabled resources and services in academic libraries. In Karnataka there are many university libraries using the internet because of

UGC-Infonet all the state university libraries are providing internet based library services. The attempt has been made to trace the literature with, related to present study as follows;

- Web-services: what they are and their importance in libraries (Cordeiro \& Carvalho, 2002)

- The role of academic libraries in universal access to print and electronic resources in the developing countries (Anunobi, 2008).

- Web Based Digital Resources and Services: Trends and Innovations (Arora, 2011).

- Web Based Information Sources and Services: A Case Study of St. Stephen's College, University of Delhi (Bhardwaj \& Walia, 2012)

- Web-Based Library Services (Bhatnaga, 2005).

- Web-services: what they are and their importance in libraries (Cordeiro \& Carvalho, 2002).

- $\quad$ Library Portal Solutions (Cox \& Yeates, 2003)

- Advancing your library's web-based services (Feldman \& Strobel. 2002).

- Web Based Library and Informatin Services (Hatua, 2010).

- Web-Based Services Expected from Libraries: A Case Study of Management Institutes in Mumbai City (Kanamadi, S., \& Kumbar, B. D. (2006).

- Academic Library Websites in Bangalore City, India: An Evaluative Study (Konnur, Rajani \& Madhusudhan, 2010).

- Web - Based Services in Library and Information Science (Kumari, 2016).

- Web $\square$ based library services in university libraries in India: an analysis of librarians' perspective (Madhusudhan \& Nagabhushanam, 2012).

- Web Services Standards, Tools and Protocols (Naik \& Shivalingaiah, 2012).

- $\quad$ ICT Application and Web based services in Library and Information Science (Sangale, 2015). 
- Library and Information Networks in India: An Overview (Shivalingaiah \& Naik, 2010).

- Web based Library services in Tamil Nadu Universities: Descriptive Study (Sundari, Jeyapragash \& Karlkikeyan. 2012).

\section{OBJECTIVES OF THE STUDY}

The main objective of the study is;

- To find out the availability of university library websites and the extent of web based library resources and facilities;

- To identify university library websites in Karnataka which have web-based library services;

- To discuss web-based resources and services offered through university library websites;

- $\quad$ To suggest the new approaches for effective use of web-based library services.

\section{SCOPE AND LIMITATIONS}

In order to realize the objectives, the study has been restricted to web-based library resources and services of nine university libraries of Karnataka state were surveyed. The selection of study libraries was based on functional web-based library services, providing via the library website. The Universities considered for the present study fall under the jurisdiction of the Government of Karnataka. The study is limited to the ten university library websites of Karnataka state and based on the evaluation criteria of the currency, accuracy, relevance, organization and structure, presentation, URL maintenance and features etc. and manual evaluation. No sampling method was adopted in view of comprehensive coverage and consistency in interpretations of the findings of the study. The study is conducted in an academic library environment consisting of respondents from different places and physical locations. The scope of the study is limited to the study of web based library service provided by the university libraries in Karnataka state. The study deals with university library web sites available during July 2016 to November 2016.

\section{METHODOLOGY}

Research is a systematic process of collecting, analyzing the data on any specific subject and to interpret the results meaningfully for common understanding. The study identified the UGC recognized universities in Karnataka state as geographical locations for conducting research, taking into account the excellent educational facilities and opportunities available in the state. In this study, the nine general university libraries have been included. The information about these universities was retrieved from the UGC website. The methodology is a content analysis of the websites of the university libraries. There were more web based library services offered by university libraries, but this study has focused on categories like, including general information about library, web OPAC, reference service, collection, circulation, and document delivery service/Inter Library Loan. The content analysis work was done during September to November, 2016. The following are the list of academic libraries selected for the study:

Table 1: Sample Universities (i.e. Selection of University Libraries)

\begin{tabular}{|c|l|l|c|}
\hline Sl. No & \multicolumn{1}{|c|}{ University Name } & \multicolumn{1}{|c|}{ Place } & Founded \\
\hline 1 & Bangalore University & Bangalore & 1964 \\
\hline 2 & Gulbarga University & Gulbarga & 1980 \\
\hline 3 & Karnatak University & Dharwad & 1949 \\
\hline
\end{tabular}




\begin{tabular}{|c|l|l|l|}
\hline \multicolumn{4}{|c|}{ Table 2: Contd., } \\
\hline 4 & KSOU & Mysore & 1996 \\
\hline 5 & KSWU & Bijapur & 2003 \\
\hline 6 & Kuvempu University & Shimoga & 1987 \\
\hline 7 & Mangalore University & Mangalore & 1980 \\
\hline 8 & Tumkur University & Tumkur & 2004 \\
\hline 9 & University of Mysore & Mysore & 1916 \\
\hline
\end{tabular}

Note: Figures as on November, 2016; KSOU=Karnataka State Open University

KSWU=Karnataka State Women's University

\section{ANALYSIS OF THE DATA}

This study provides the library services availability, its functions, features and types of services, organization and structure; presentation; maintenance; and different features of the library web services. Qualitative and quantitative results were analyzed and presented in the following sections.

\section{Universities, Libraries in Karnataka}

In the beginning, the investigator obtained preliminary information related to respondent universities and their libraries from the websites of the respective universities. The web address (URL) of websites of individual university from where the basic information is obtained is given in Table 2. All the universities have their independent university URL and

Table 2: List of Universities with Website Address (URL)

\begin{tabular}{|c|c|c|c|}
\hline Sl. No. & University Name & Emblem & URL \\
\hline 1 & Bangalore University & & http://bangaloreuniversity.ac.in \\
\hline 2 & Gulbarga University & & http://www. http://gug.ac.in/ \\
\hline 3 & Karnatak University & & http://www.kud.ac.in \\
\hline 4 & KSOU & 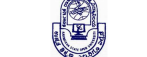 & http://karnatakastateopenuniversity.in \\
\hline 5 & KSWU & & http://www.kswu.ac.in/ \\
\hline 6 & Kuvempu University & 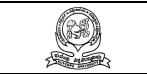 & http://www.kuvempu.ac.in \\
\hline 7 & Mangalore University & & http://www.mangaloreuniversity.ac.in \\
\hline 8 & Tumkur University & $\therefore$ & http://www.tumkuruniversity.ac.in \\
\hline 9 & University of Mysore & 量, & http://www.uni-mysore.ac.in \\
\hline
\end{tabular}

\section{University Library URLs}

The Table 3 shows that all the university libraries have their own web site address. The majority of the sites are coming under "ac.in" and only Karnataka State Open University is having "in” domain name. Each university has slogan related emblems. 
Table 3: Separate Universities Library Website (URL)

\begin{tabular}{|c|l|l|}
\hline Sl. No. & \multicolumn{1}{|c|}{ University Name } & \multicolumn{1}{|c|}{ Library URL } \\
\hline 1 & Bangalore University & No \\
\hline 2 & Gulbarga University & http://guglibrary.net/ \\
\hline 3 & Karnatak University & http://www.kudlibrary.org/ \\
\hline 4 & KSOU & No \\
\hline 5 & KSWU & No \\
\hline 6 & Kuvempu University & No \\
\hline 7 & Mangalore University & No \\
\hline 8 & Tumkur University & No \\
\hline 9 & University of Mysore & No \\
\hline
\end{tabular}

Note: Figures as on November, 2016; KSOU=Karnataka State Open University

\section{KSWU=Karnataka State Women's University}

Out of nine universities, seven university library websites are under the university web domain and only two university libraries have their own independent library websites.

\section{Table 4: Digital Library}

\begin{tabular}{|c|l|l|}
\hline Sl. No. & \multicolumn{1}{|c|}{ University Name } & \multicolumn{1}{c|}{ Digital Library } \\
\hline 1 & Bangalore University & http://eprints-bangaloreuniversity.in/ * \\
\hline 2 & Gulbarga University & No \\
\hline 3 & Karnatak University & https://sites.google.com/site/kudlibrary2014/ \\
\hline 4 & KSOU & No \\
\hline 5 & KSWU & No \\
\hline 6 & Kuvempu University & http://kuls-ir.kuvempu.ac.in/ \\
\hline 7 & Mangalore University & No \\
\hline 8 & Tumkur University & http://dl.tumkuruniversity.ac.in/ * \\
\hline 9 & University of Mysore & http://eprints.uni-mysore.ac.in/ \\
Note: Figures as on November, 2016; & KSOU=Karnataka State Open University \\
KSWU Karnataka State Women's University $\quad *$ Access denied
\end{tabular}
K

The Table 4 explores the digital library website information. Only four university libraries have their own digital library websites, but only two URLs are working remain two URLs access denied.

Table 5: Remote Access

\begin{tabular}{|c|c|c|}
\hline Sl. No. & University Name & Remote Access \\
\hline 1 & Bangalore University & http://14.139.155.5:2048/login \\
\hline 2 & Gulbarga University & No \\
\hline 3 & Karnatak University & http://14.139.155.103:2048/* \\
\hline 4 & KSOU & No \\
\hline 5 & KSWU & No \\
\hline 6 & Kuvempu University & No \\
\hline 7 & Mangalore University & http://218.248.47.185:2048/login \\
\hline 8 & Tumkur University & No \\
\hline 9 & University of Mysore & http://ezproxy.uni-mysore.ac.in:2048/login \\
\hline \multicolumn{3}{|c|}{ Note: Figures as on November, 2016; } \\
\hline
\end{tabular}

Table 5 shows that out of nine universities only three universities having the Remote Access facilities based on login and passwords access points. Out of these three URLs Karnataka University, Dharwad access point is disabled. 
Table 6: Web OPAC

\begin{tabular}{|c|l|l|}
\hline Sl. No. & \multicolumn{1}{|c|}{ University Name } & \multicolumn{1}{c|}{ URL } \\
\hline 1 & Bangalore University & http://bublib-koha.informindia.co.in/ \\
\hline 2 & Gulbarga University & http://libcat-guglib.informindia.co.in/ \\
\hline 3 & Karnatak University & http://kul-koha.informindia.co.in/ \\
\hline 4 & KSOU & http://192.168.10.4:8080/newgenlibctxt/Opac2_0.jsp \\
\hline 5 & KSWU & No \\
\hline 6 & Kuvempu University & $172.17 .0 .17 *$ \\
\hline 7 & Mangalore University & http://218.248.47.185:8080/jopacv11/html/SearchForm \\
\hline 8 & Tumkur University & http://library.tumkuruniversity.ac.in/ * \\
\hline 9 & University of Mysore & http://libcatmysore-koha.informindia.co.in/ \\
\hline
\end{tabular}

Note: Figures as on November, 2016; $\quad$ KSOU=Karnataka State Open University

$$
\text { KSWU=Karnataka State Women's University } \quad * \text { Access Denied }
$$

The automated library provides the OPAC service to the users. The Table 6 describes the OPAC facilities available on the internet. Except Karnataka State Women's University, Bijapur remaining eight universities has their own library OPAC facilities.

Table 7: E-Resources Highlights in the Main Page of the Sites

\begin{tabular}{|c|l|l|l|l|l|l|}
\hline SI. No. & \multicolumn{1}{|c|}{ University Name } & E-Resources & UGC-Infonet & $\begin{array}{c}\text { Online } \\
\text { Databases }\end{array}$ & $\begin{array}{c}\text { Ask a } \\
\text { Librarian }\end{array}$ & FAQ \\
\hline 1 & Bangalore University & Yes & Yes & Yes & No & Yes \\
\hline 2 & Gulbarga University & Yes & Yes & Yes & Yes & No \\
\hline 3 & Karnatak University & Yes & Yes & Yes & No & No \\
\hline 4 & KSOU & Yes & Yes & Yes & No & No \\
\hline 5 & KSWU & No & No & No & No & No \\
\hline 6 & Kuvempu University & Yes & No & Yes & No & No \\
\hline 7 & Mangalore University & Yes & No & Yes & No & No \\
\hline 8 & Tumkur University & Yes & Yes & Yes & No & No \\
\hline 9 & University of Mysore & Yes & Yes & Yes & No & No \\
\hline
\end{tabular}

Note: Figures as on November, 2016; KSOU=Karnataka State Open University

KSWU=Karnataka State Women's University

The Table 7 shows that, except Karnataka State Women's University library all libraries have library web OPAC facilities and two university library OPAC URLs are access denied.

\section{Facilities and Services}

The subject specialization is an important task among the universities which have been chosen for the study. After review of the details about universities the investigator has identified that all of them are general in nature and similar in subject areas. The Table 8 shows the number of departments available within the university premises.

Table 8: Number of Department in the Universities

\begin{tabular}{|c|l|c|c|c|c|c|}
\hline Sl. No & \multicolumn{1}{|c|}{$\begin{array}{c}\text { Name of the } \\
\text { University }\end{array}$} & $\begin{array}{c}\text { Science/ } \\
\text { Tech. }\end{array}$ & $\begin{array}{c}\text { Social } \\
\text { Science }\end{array}$ & $\begin{array}{c}\text { Commerce / } \\
\text { Management }\end{array}$ & Education & Total \\
\hline 1 & Bangalore University & 19 & 18 & 03 & 01 & 41 \\
\hline 2 & Gulbarga University & 15 & 17 & 02 & 03 & 37 \\
\hline 3 & Karnatak University & 13 & 28 & 02 & 01 & 44 \\
\hline 4 & KSOU & 12 & 13 & 02 & 01 & 28 \\
\hline 5 & KSWU & 12 & 13 & 02 & 01 & 28 \\
\hline 6 & Kuvempu University & 23 & 14 & 05 & 02 & 44 \\
\hline
\end{tabular}


Web Enabled Library Resources and Services: A Comparative Study of University Libraries in Karnataka State

\begin{tabular}{|l|l|l|c|c|c|c|}
\hline \multicolumn{7}{|c|}{ Table 8: Contd., } \\
\hline 7 & Mangalore University & 15 & 08 & 03 & 01 & 27 \\
\hline 8 & Tumkur University & 08 & 08 & 02 & 00 & 18 \\
\hline 9 & University of Mysore & 23 & 20 & 02 & 02 & 47 \\
\hline
\end{tabular}

Note: Figures as on November, 2016; $\quad$ KSOU=Karnataka State Open University

\section{KSWU=Karnataka State Women's University}

The Table 8 shows the University of Mysore has a maximum of 47 post graduation departments, whereas the Tumkur University has least numbers i.e. 18 post graduation departments.

\section{Library Infrastructures}

The user satisfaction is the ultimate objective of the university library. It depends on the well furnished infrastructure by means of skilled manpower and ICT enabled information sources and services are an important factor in the electronic era. Primarily the computer forms the backbone of the network. Affordable computer technology, rapid change in telecommunication and emerging network infrastructure play a dominant role information resource sharing. The use ICT's in libraries has resulted in the creation, integration and utilization of e-resources and in-house resources in addition to other internet based services. Prerequisites essential to form an internet access, hardware, software, Netware, human ware, integrated library system etc. are very essential. (Rao, Sastry, \& Reddy, 2005). In order to ascertain the status of internet based services and availability of infrastructure is an important basic component in order to support the ICT based functionality and services to the academic communities. (Anunobi, 2008) The opinions of the librarians about Infrastructure facilities have been made available in university libraries and are presented in the Table 9a and $9 \mathrm{~b}$

Table 9a: Infrastructure Available within the Library

\begin{tabular}{|c|l|c|c|c|c|c|c|}
\hline \multirow{2}{*}{ SI. No. } & \multirow{2}{*}{ University Name } & \multirow{2}{*}{ Network } & \multirow{2}{*}{ UPS } & \multicolumn{2}{c|}{$\begin{array}{c}\text { Computers } \\
\text { Lab }\end{array}$} & \multicolumn{3}{|c|}{ Operating Systems } \\
\cline { 6 - 8 } & & & & Win & Linux & Mac \\
\hline 1 & Bangalore University & $\sqrt{n}$ & $\sqrt{ }$ & $\sqrt{ }$ & $\sqrt{ }$ & $\sqrt{ }$ & $\mathbf{X}$ \\
\hline 2 & Gulbarga University & $\sqrt{ }$ & $\sqrt{ }$ & $\sqrt{ }$ & $\sqrt{ }$ & $\sqrt{ }$ & $\mathbf{X}$ \\
\hline 3 & Karnatak University & $\sqrt{ }$ & $\sqrt{ }$ & $\sqrt{ }$ & $\sqrt{ }$ & $\sqrt{ }$ & $\mathbf{X}$ \\
\hline 4 & KSOU & $\sqrt{ }$ & $\sqrt{ }$ & $\sqrt{ }$ & $\sqrt{ }$ & $\sqrt{ }$ & $\mathbf{X}$ \\
\hline 5 & KSWU & $\sqrt{ }$ & $\sqrt{ }$ & $\sqrt{ }$ & $\sqrt{ }$ & $\sqrt{ }$ & $\mathbf{X}$ \\
\hline 6 & Kuvempu University & $\sqrt{ }$ & $\sqrt{ }$ & $\sqrt{ }$ & $\sqrt{ }$ & $\sqrt{ }$ & $\mathbf{X}$ \\
\hline 7 & Mangalore University & $\sqrt{ }$ & $\sqrt{ }$ & $\sqrt{ }$ & $\sqrt{ }$ & $\sqrt{ }$ & $\mathbf{X}$ \\
\hline 8 & Tumkur University & $\sqrt{ }$ & $\sqrt{ }$ & $\sqrt{ }$ & $\sqrt{ }$ & $\sqrt{ }$ & $\mathbf{X}$ \\
\hline 9 & University of Mysore & $\sqrt{ }$ & $\sqrt{ }$ & $\sqrt{ }$ & $\sqrt{ }$ & $\sqrt{ }$ & $\mathbf{X}$ \\
\hline
\end{tabular}

Note: Figures as on November, 2016; $\quad$ KSOU=Karnataka State Open University

\section{KSWU=Karnataka State Women's University}

The Table 9a shows that all the universities have Network, UPS, Computers Lab, operating systems except Macintosh OS all the universities are familiar with windows and Linux Operating System. The Table 9b focuses on the Internet connection/access, access type Library automation and security privileges. All the universities follow the UGC norms and maintain the same functions and procedures.

Table 9b: Infrastructure Available within the Library

\begin{tabular}{|l|c|c|c|c|c|c|}
\hline \multicolumn{1}{|c|}{ University Name } & $\begin{array}{c}\text { Internet } \\
\text { Access }\end{array}$ & ISP & $\begin{array}{c}\text { Access } \\
\text { Type }\end{array}$ & $\begin{array}{c}\text { Library } \\
\text { Automation }\end{array}$ & $\mathbf{2 4 x 7}$ & $\begin{array}{c}\text { Proxy / } \\
\text { Firewall }\end{array}$ \\
\hline Bangalore University & $\sqrt{ }$ & BSNL & Free & $\sqrt{ }$ & $\sqrt{ }$ & $\sqrt{ }$ \\
\hline Gulbarga University & $\sqrt{ }$ & BSNL & Free & $\sqrt{ }$ & $\sqrt{ }$ & $\sqrt{ }$ \\
\hline
\end{tabular}




\begin{tabular}{|l|c|l|l|l|l|l|}
\hline \multicolumn{7}{|c|}{ Table 9b: Contd., } \\
\hline Karnatak University & $\sqrt{ }$ & BSNL & Free & $\sqrt{ }$ & $\sqrt{ }$ & $\sqrt{ }$ \\
\hline KSOU & $\sqrt{ }$ & BSNL & Free & $\sqrt{ }$ & $\sqrt{ }$ & $\sqrt{ }$ \\
\hline KSWU & $\sqrt{ }$ & BSNL & Free & $\sqrt{ }$ & $\sqrt{ }$ & $\sqrt{ }$ \\
\hline Kuvempu University & $\sqrt{ }$ & BSNL & Free & $\sqrt{ }$ & $\sqrt{ }$ & $\sqrt{ }$ \\
\hline Mangalore University & $\sqrt{ }$ & BSNL & Free & $\sqrt{ }$ & $\sqrt{ }$ & $\sqrt{ }$ \\
\hline Tumkur University & $\sqrt{ }$ & BSNL & Free & $\sqrt{ }$ & $\sqrt{ }$ & $\sqrt{ }$ \\
\hline University of Mysore & $\sqrt{ }$ & BSNL & Free & $\sqrt{ }$ & $\sqrt{ }$ & $\sqrt{ }$ \\
\hline
\end{tabular}

Note: Figures as on November, 2016; KSOU=Karnataka State Open University

KSWU=Karnataka State Women's University

\section{Library Information}

The library information available in the respective university libraries have been shown at the Table 10

The Table 10 reveals that the maximum numbers of software tools are available in Kuvempu University library followed by the Bangalore University library. Whereas, the Karnatak University and Mangalore University libraries don't have sufficient infrastructure facilities as compared to other university libraries.

Table 10: Library Information

\begin{tabular}{|c|l|c|c|c|c|}
\hline Sl. No. & \multicolumn{1}{|c|}{ University Name } & $\begin{array}{c}\text { Library } \\
\text { Collections }\end{array}$ & $\begin{array}{c}\text { Staff } \\
\text { Details }\end{array}$ & $\begin{array}{c}\text { Service } \\
\text { List }\end{array}$ & $\begin{array}{c}\text { Library } \\
\text { Timings }\end{array}$ \\
\hline 1 & Bangalore University & $\sqrt{ }$ & $\sqrt{ }$ & $\mathrm{X}$ & $\sqrt{ }$ \\
\hline 2 & Gulbarga University & $\sqrt{ }$ & $\sqrt{ }$ & $\mathrm{X}$ & $\mathrm{X}$ \\
\hline 3 & Karnatak University & $\sqrt{ }$ & $\sqrt{ }$ & $\mathrm{X}$ & $\mathrm{X}$ \\
\hline 4 & KSOU & $\mathrm{X}$ & $\sqrt{ }$ & $\sqrt{ }$ & $\sqrt{ }$ \\
\hline 5 & KSWU & $\mathrm{X}$ & $\sqrt{ }$ & $\sqrt{ }$ & $\sqrt{ }$ \\
\hline 6 & Kuvempu University & $\sqrt{ }$ & $\sqrt{ }$ & $\sqrt{ }$ & $\mathrm{X}$ \\
\hline 7 & Mangalore University & $\mathrm{X}$ & $\sqrt{ }$ & $\sqrt{ }$ & $\sqrt{ }$ \\
\hline 8 & Tumkur University & $\sqrt{ }$ & $\sqrt{ }$ & $\sqrt{ }$ & $\mathrm{X}$ \\
\hline 9 & University of Mysore & $\sqrt{ }$ & $\sqrt{ }$ & $\sqrt{ }$ & $\sqrt{ }$ \\
\hline
\end{tabular}

Note: Figures as on November, 2016; $\quad$ KSOU=Karnataka State Open University

KSWU=Karnataka State Women's University

\section{CONCLUSIONS}

The purpose of this study is to present the current status and use of the web enabled library resources and services provide by the university libraries in Karnataka. The study observes that the university libraries considered in the current study is equipped with good resources, large number of ICT facilities with internet connectivity. The transfer of library services to the web based environment helps the users to find, evaluate, and use information effectively. As the outcome of the study it would propose measures for the improvement of web based information services in University libraries in Karnataka.

\section{REFERENCES}

1. Anunobi, C. V. (2008). The role of academic libraries in universal access to print and electronic resources in the developing countries. Library Philosophy and Practice, May, 1-5.

2. Arora, J. (2011). Web Based Digital Resources and Services: Trends and Innovations. Retrieved 10-10-2016, from https://www.researchgate.net/publication/228595212_Web-Based_Digital_Resources_and_Services_Trends_and_Innovations

3. Bhardwaj, R. K., \& Walia, P. K. (2012). Web Based Information Sources and Services: A Case Study of St. Stephen's College, 
Web Enabled Library Resources and Services: A Comparative

Study of University Libraries in Karnataka State

University of Delhi. Library Philosophy and Practice 1-18.

4. Bhatnaga, A. (2005). Web-Based Library Services. Paper presented at the 3rd Convention PLANNER -2005, Assam Univ. Silchar,.

5. Borasky, D. (1999). Analysis of Web-Based Library Services. University of North Carolina, Chapel Hill, North Carolina.

6. Chandra, H. (2002). Web-based document delivery service at the central library of IIT Madras. Paper presented at the CALIBER 2002, Japur.

7. Cordeiro, M. I., \& Carvalho, J. d. (2002). Web-services: what they are and their importance in libraries Vine, 32(4), 46-62.

8. Cox, A., \& Yeates, R. (2003). Library Portal Solutions. Aslib Proceedings, 55(3), 155-165.

9. Feldman, S., \& Strobel., T. (2002). Advancing your library's web-based services. ERIC Digest.

10. Hatua, S. R. (2010). Web Based Library and Information Services. Retrieved 2-8-2016, from http://shatua.tripod.com/DRTCseminar.html

11. Kanamadi, S., \& Kumbar, B. D. (2006). Web-Based Services Expected from Libraries: A Case Study of Management Institutes in Mumbai City Webology, 3(2).

12. Konnur, P. V., Rajani, S., \& Madhusudhan, M. (2010). Academic Library Websites in Bangalore City, India: An Evaluative Study. Library Philosophy and Practice 2010.

13. Kumari, N. (2016). Web-Based Services in Library and Information Science IJNGLT, 2(1), 1-8.

14. $L i, L ., \& L i, L .(2006)$. Leveraging quality web $\square$ based library user services in the digital age. Library Management, 27(6/7), $390-400$.

15. Madhusudhan, M., \& Nagabhushanam, V. (2012). Use of Web-Based Library Services in Select University Libraries in India: A Study International Journal of Library and Information Studies, 2(1), 1-20.

16. Madhusudhan, M., \& Nagabhushanam, V. (2012). Web $\square$ based library services in university libraries in India: an analysis of librarians' perspective. The Electronic Librar, 30(5), 569-588.

17. Mirza, M. S., \& Mahmood, K. (2009). Web-based services in university libraries: a Pakistani perspective. Library Philosophy and Practice 2009, 1-6.

18. Moore, N. (2000). The internet and the library. Library Review, 49(9), 422-428.

19. Naik, U., \& Shivalingaiah, D. (2008). Comparative Study of Web 1.0, Web 2.0 and Web 3.0. Paper presented at the 6th International CALIBER 2008 University of Allahabad, Allahabad.

20. Naik, U., \& Shivalingaiah, D. (2012). Web Services Standards, Tools and Protocols. In A. Osswald, S. M. Z. Ahmed, Chandran, P. Rajendran, S. K. A. Kumar, P. M. Rao \& S. Baskaran. (Eds.), Dynamics of Librarianships in the Knowledge Society (Vol. 1, pp. 385-403). Delhi: B R Publishing Corporation.

21. Pathak, S. K., Mishra, A., \& Sahoo, G. (2008). Future of Web Based Library and Information Services: An Indian Scenario. Paper presented at the PLANNER 2008, Nagaland University, Nagaland.

22. Rao, K. T., Sastry, M. S. V. R., \& Reddy, S. C. (2005). Evolution of technology in brief internet technology - Its use in academic libraries central library, SSSIHL an Example. Paper presented at the 3rd Convention PLANNER -2005r, Assam Univ., Silchar.

23. Sangale, D. B. (2015). ICT Application and Web based services in Library and Information Science ASM's INTERNATIONAL E-Journal on Ongoing Research in Management and IT, 9-14. 
24. Shivalingaiah, D., \& Naik, U. (2010). Library and Information Networks in India: An Overview. Paper presented at the Knowledge Banks and Information Networking (KKBNET 2010, National Institute of Technology, Surathkal.

25. Sundari, S. K., Jeyapragash, B., \& Karlkikeyan. (2012). Web based Library services in Tamil Nadu Universities: Descriptive Study. Paper presented at the National Conference on Innovative Library Services in Digital Era, ZOIZ. DnMCIi T. Pollacht.

26. UGC. (2015). State University. Retrieved 10-11-2016, from http://www.ugc.ac.in/stateuniversitylist.aspx?id=12\&Unitype=2 